\title{
KELIMPAHAN JENIS TERIPANG (Holothuroidea) \\ DI RATAAN TERUMBU KARANG DAN LERENG TERUMBU KARANG PANTAI PANCURAN BELAKANG PULAU KARIMUNJAWA JEPARA
}

\author{
The Abundance of Sea Cucumbers Type (Holothuroidea) on The Coral Reef Flat And Coral Reef Slope of \\ Pancuran Belakang Beach Karimunjawa Islands Jepara
}

Muhamad Fadli, Suryanti, Ruswahyuni ${ }^{l}$

Program Studi Manajemen Sumberdaya Perairan, Jurusan Perikanan

Fakultas Perikanan dan Ilmu Kelautan, Universitas Diponegoro

\begin{abstract}
ABSTRAK
Kepulauan Karimun Jawa Jepara Jawa Tengah sangat terkenal akan kekayaan sumberdaya alam yang ada di dalam laut. Jenis-jenis biota yang beragam hidup di dalamnya.Tujuan dari penelitian ini adalah mengetahui kelimpahan teripang pada lokasi rataan terumbu karang dan lereng terumbu karang serta mengetahui hubungan antara kelimpahan teripang dengan penutupan terumbu karang di lokasi penelitian. Metode yang digunakan adalah metode line transek. Hasil penelitian didapatkan prosentase penutupan karang hidup pada rataan terumbu karang 65,69\% dan pada lereng 69,26\%. Kelimpahan individu teripang pada daerah rataan terumbu karang $37 \mathrm{ind} / 300 \mathrm{~m}^{2}$ dan pada lereng terumbu karang $11 \mathrm{ind} / 300 \mathrm{~m}^{2}$. Berdasarkan hasil Uji Test "T" di dapatkan kelimpahan jenis teripang yang paling banyak adalah pada stasiun A rataan terumbu karang.
\end{abstract}

Kata Kunci : Penutupan Karang, Teripang, Kelimpahan.

\begin{abstract}
Karimunjawa Islands Jepara Central Java is very famous for its rich natural resources in the sea. The type of a biota diverse living in the sea. The purpose of research was to determine the abundance of sea cucumbers on coral reef and reef slope locations and determine the relationship between the abundance of sea cucumbers by closing coral reefs in the research sites. The method used is this research was line transect .The result obtained percentage live coral reef $65.69 \%$ and $69.26 \%$ on big slopes. Individual abundance averaging cucumbers on coral reef area of $37 \mathrm{ind} / 300 \mathrm{~m}^{2}$ and on the reef slope at $11 \mathrm{ind} / 300 \mathrm{~m}^{2}$. Based on the results of Test Test "T" can be concluded that the abundance of sea cucumber is the most coral reef in the area.
\end{abstract}

Keywords: Coral Closure, Sea Cucumbers, Abundance. 


\section{PENDAHULUAN}

Terumbu karang merupakan salah satu dari ekosistem-ekosistem pantai yang memiliki tingkat produktivitas yang tinggi dan keanekaragaman dari biota yang berasosiasi sangat beragam. Terumbu karang terdiri atas polip-polip karang dan organisme-organisme kecil lain yang hidup dalam koloni. Bila polip karang mati akan meninggalkan struktur yang keras, terdiri atas bahan mineral dan mengandung kalsium (Lime stone). Terumbu karang dapat berfungsi sebagai pelindung (Shelter) untuk berbagai fauna yang hidup di dalam kompleks habitat terumbu karang ini seperti sponge, akar bahar, kima, berbagai ikan hias, ikan kerapu, anemon, teripang, lobster, moluska dan lain-lain (Murdiyanto, 2003).

Menurut Nontji (2005) teripang (Holothuroidea) merupakan golongan yang paling umum di jumpai. Hewan ini banyak terdapat di paparan terumbu karang kemudian juga di pantai berbatu atau yang berlumpur. Teripang dapat dijumpai tidak hanya di perairan dangkal, ada juga yang hidup di laut dalam, bahkan di palung laut yang terdalam di dunia pun terdapat teripang. Di laut banda yang dalamnya sekitar 7.000 meter terdapat teripang Paroriza greview. Di palung jawa yang juga dalamnya sekitar 7.000 meter ditemukan antara lain teripang Periamna naresi dan Elpidia sundensis.

Kepulauan Karimun Jawa Jepara Jawa Tengah sangat terkenal akan kekayaan sumberdaya alam yang ada di dalam laut. Jenis-jenis biota yang beragam hidup di dalamnya. Seperti pada daerah ekosistem terumbu karang banyak biota-biota yang berasosiasi di daerah tersebut untuk keperluan mencari makan, melakukan pemijahan dan juga sebagai tempat perlindungan dari para predator. Teripang (Holothuroidea) juga hidup di daerah terumbu karang yang bertujuan untuk mencari makan.

Kurangnya pengetahuan dan informasi tentang teripang (Holothuroidea) melatar belakangi dilaksanakan penelitian tentang Kelimpahan teripang (Holothuroidea) pada daerah rataan terumbu karang dengan lereng terumbu karang. Oleh sebab itu, dengan mengamati prosentase penutupan jenis karang, kelimpahan individu teripang dan kondisi perairan, maka dapat dilihat keterkaitan antara karang, teripang dan kondisi perairan. Dengan diketahuinya faktor-faktor yang mendukung kehidupan teripang, maka diharapkan dapat membantu untuk usaha pelestariannya di masa sekarang dan yang akan datang serta dapat ikut dalam rangka pemeliharaan keseimbangan ekosistem laut.

Tujuan dari penelitian ini adalah untuk mengetahui prosentase tutupan terumbu karang di daerah rataan terumbu karang dan lereng terumbu karang serta mengetahui perbedaan kelimpahan teripang (Holothuroidea) yang terdapat pada daerah rataan dan lereng terumbu karang Penelitian ini dilaksanakan pada Bulan Maret 2013 di Perairan Pulau Karimunjawa, Balai Taman Nasional Karimunjawa, Jepara Jawa Tengah.

\section{METODOLOGI PENELITIAN}

Materi yang digunakan dalam penelitian ini adalah teripang (Holothruroidea) yang terdapat pada rataan terumbu karang dan lereng terumbu karang. Alat dan bahan yang digunakan disesuaikan dengan metode yang dipakai yaitu metode line transek dan kuadrat transek.

Alat

Alat yang digunakan dalam penelitian ini yaitu line transek 50 meter, kuadrat transek 2x2 meter, Global Positioning System (GPS), Refraktrometer, Termometer, Sabak, pH paper, Kamera bawah air, Secchi disc, Buku identifikasi karang dan teripang, Alat Tulis, Plastik sampel dan masker snorkel. Metode

Metode yang digunakan dalam penelitian ini adalah metode observasi. Menurut Irawan (2002), menyatakan bahwa metode (penelitian) observasi adalah penelitian yang pengambilan datanya bertumpu pada pengamatan langsung terhadap objek penelitian. Biasanya, penelitian dengan metode observasi memerlukan kesabaran yang luar biasa dari penelitiannya, menyita banyak waktu dan tenaga, dan kejelian peneliti untuk "menangkap" elemen-elemen paling penting dari objek penelitiannya

\section{Penentuan Lokasi Sampling}

Lokasi pengambilan sampel atau lokasi sampling berada di Pantai Pancuran Belakang Kepulauan Karimunjawa Jepara Jawa Tengah. Sebelum melakukan sampling terlebih dahulu dilakukan survey pendahuluan untuk menentukan lokasi titik sampling. Setelah melakukan survey pendahuluan didapatkan dua lokasi titik sampling yaitu lokasi A rataan terumbu karang dan lokasi B lereng terumbu karang untuk melihat kelimpahan jenis teripang. Pada setiap titik sampling terdapat 3 line transek dengan panjang masing-masing 50 meter.

\section{Metode Sampling}

Metode yang digunakan dalam pengambilan data prosentase penutupan karang adalah dengan menggunakan metode line transek, sedangkan untuk pengambilan data kelimpahan Teripang (Holothuroidea) adalah menggunakan metode kuadran transek. Pengamatan ini dilakukan pada daerah rataan terumbu karang dan lereng terumbu karang. Menurut Supriharyono (2000) menyatakan bahwa berbeda dengan kuadrat transek, pengukuran dengan transek garis menggunakan alat ukur berupa meteran berskala dengan panjang 50 meter. Prosentase tutupan karang baik yang hidup maupun mati dan substrat diukur dari perbandingan panjang parameter-parameter tersebut dengan panjang meteran yang digunakan. 


\section{Pelaksanaan Kegiatan}

Tahap pelaksanaan penelitian dibagi menjadi 3 bagian kegiatan, yaitu pengambilan data penutupan karang, pengambilan data kelimpahan teripang (Holothruoidea) dan pengukuran kualitas air.

Pelaksanaan kegiatan dimulai dengan pengambilan data penutupan terumbu karang dengan cara memasang garis line transek sepanjang 50 meter sebanyak 3 buah, lalu melakukan pengamatan serta pendataan tutupan jenis karang di sepanjang garis line transek dengan cara snorkling pada rataan terumbu karang dan penyelaman pada lereng terumbu karang.

Pengambilan data kelimpahan teripang (Holothuroidea) dengan menggunakan kuadrat transek yang berukuran $2 \times 2$ meter yang cara penggunaannya ditelakan pada garis line transek lalu melihat jenis teripang yang ada didalamnya dan melakukan penghitungan kelimpahan teripang tersebut.

Pelaksanaan kegiatan yang terakhir adalah pengukuran parameter kualitas air. Parameter yang diukur diantaranya adalah suhu, arus, kedalaman, kecerahan, $\mathrm{pH}$ dan salinitas.

\section{Analisis Data Lapangan}

Hipotesis ini digunakan untuk menduga ada tidaknya hubungan kelimpahan teripang (Holothuroidea) pada daerah rataan terumbu karang dengan lereng terumbu karang di pantai pancuran belakang Kepulauan Karimunjawa, Jepara Jawa Tengah. Hipotesis yang digunakan dalam penelitian ini adalah hubungan kelimpahan teripang (Holothuroidea) pada penutupan terumbu karang.

$\mathrm{H}_{0} \quad=$ Tidak ada perbedaan kelimpahan teripang pada tutupan terumbu karang

$\mathrm{H}_{1} \quad$ = Ada perbedaan kelimpahan teripang pada tutupan terumbu karang

Probabilitas

Kaidah pengambilan keputusan adalah sebagai berikut :

$=P$ value $\leq\left(\alpha=0,05\right.$, maka terima $\mathrm{H}_{1}$ tolak $\left.\mathrm{H}_{0}\right)$

$=\mathrm{P}$ value $>\left(\alpha=0,05\right.$, maka terima $\mathrm{H}_{0}$ tolak $\left.\mathrm{H}_{1}\right)$

Uji Tes "T"

Test "T" adalah salah satu uji statistik yang digunakan untuk mengetahui ada atau tidaknya perbedaan yang signifikan (meyakinkan) dari dua buah mean sampel (dua buah variabel yang dikomparatifkan).

\section{Persentase Penutupan Karang}

Persentase karang hidup, karang mati, pasir dan pecahan karang, dihitung dengan menggunakan rumus (Odum, 1993) :

Keterangan:

$$
C=\frac{L i}{L} \times 100 \%
$$

C : Persentase tutupan karang

li : Panjang tutupan karang jenis ke-i

L $\quad$ : Panjang total transek

Menurut Dahuri et al (2001), kriteria penilaian kondisi terumbu karang adalah berdasarkan

Persentase penutupan karang hidup dengan kategori sebagai berikut:
1. Kategori rusak
$: 0-25 \%$
2. Kategori sedang
$: 25-50 \%$
3. Kategori baik
$: 50-75 \%$
4. Kategori sangat baik
$: 75-100 \%$

\section{Indeks Keanekaragaman, Indeks Keseragaman dan Dominansi}

Menurut Odum (1971) Indeks Shannon-Wiener digunakan untuk menghitung indeks keanekaragaman (diversity index) jenis, dan indeks keseragaman dihitung dengan rumus sebagai berukut :

\section{Indeks Keanekaragaman}

Keterangan :

$$
H^{\prime}=-\sum_{i=1}^{i} P i \operatorname{Ln} P i
$$

H' : Indeks Keanekaragaman Jenis

ni : Jumlah individu jenis ke-i

$\mathrm{N} \quad$ : Jumlah total individu

$\mathrm{S} \quad$ : Jumlah genus penyusun komunitas

$\mathrm{Pi} \quad:$ ni/N

Tabel 1. Kisaran stabilitas perairan berdasarkan indeks keanekaragaman

\begin{tabular}{ccc}
\hline No. & Kisaran stabilitas & Keanekaragaman \\
\hline 1. & $0<\mathrm{H}^{\prime} \leq 1$ & Rendah (tidak stabil) \\
2. & $1<\mathrm{H}^{\prime} \leq 2$ & Sedang \\
3. & $\mathrm{H}^{\prime}>2$ & Tinggi (stabil) \\
\hline
\end{tabular}




\section{Indeks Keseragaman}

Keterangan:

$$
e=\frac{H^{\prime}}{H \max }
$$

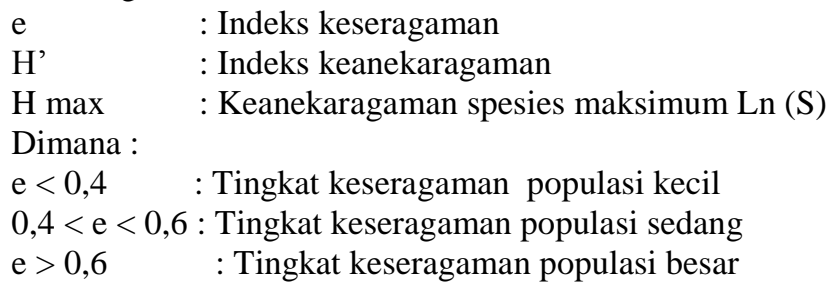

\section{Indeks Dominasi}

Untuk menghitung indeks dominansi digunakan rumus Odum (1993) sebagai berikut:

Keterangan :

$$
D=\left(\frac{n i}{N}\right)^{2}
$$

$$
\begin{array}{ll}
\mathrm{D} & \text { : Indeks dominansi } \\
\mathrm{ni} & \text { : Jumlah individu spesies ke-i } \\
\mathrm{N} & \text { : Jumlah total spesies }
\end{array}
$$

\section{Kelimpahan Individu Teripang (Holothuroidea)}

Kelimpahan Teripang (Holothuroidea) dihitung dengan menggunakan rumus dalam Odum (1993), yaitu :

Keterangan:

$$
K R=\frac{n i}{N} \times 100 \%
$$

$\begin{array}{ll}\mathrm{KR} & \text { : Kerapatan Relatif } \\ \mathrm{ni} & \text { : Jumlah Individu } \\ \mathrm{N} & \text { : Jumlah total individu }\end{array}$

\section{HASIL}

\section{Gambaran Umum Lokasi Penelitian}

Taman Nasional Karimunjawa menurut Keputusan Mentri Kehutanan No. 161/ Kpts-II/ 1986 tanggal 9 April 1986 dikukuhkan sebagai Cagar Alam dan keputusan Mentri Kehutanan No. 78/ Kpts-II/1999 tanggal 22 Februari 1999 ditetapkan perubahan fungsi Cagar Alam Karimunjawa menjadi Taman Nasional Karimunjawa. Tahun 2001 sebagian luas kawasan TN Karimunjawa seluas 110.117,30 Ha ditetapkan sebagai Kawasan Pelestarian Alam Perairan dengan keputusan Menhut No. 74/Kpts-II/2001. Taman Nasional Karimunjawa secara administratif termasuk wilayah Kabupaten Jepara, Provinsi Jawa Tengah yang memiliki letak geografis $5^{0} 42^{\prime}-6^{0} 00^{\prime}$ LS dan $110^{\circ} 07^{\prime}-110^{0} 37^{\prime}$ BT dengan luas keseluruhan 111. 625 Ha dan temperatur udara sekitar $23^{0}-32^{\circ} \mathrm{C}$ dengan ketinggian tempat $0-605$ meter dpl yang meliputi 22 pulau yang mempunyai ekosistem asli dengan keanekaragaman hayati yang tinggi mulai dari daratan hingga perairannya yang perlu dipertahankan dan dimanfaatkan secara lestari dan bijaksana (BTNKj, 2008).

Pantai Pancuran Belakang terletak dibagian timur Pulau Karimunjawa. Letak titik koordinat Pantai Pancuran Belakang, Taman Nasional Karimunjawa terletak pada titk kordinat $S=5^{\circ} 53^{\prime} 08,5^{\prime}$ ' dan pada $\mathrm{E}=$ $110^{\circ} 26^{\prime} 55,62$ '. Pantai Pancuran Belakang ini merupakan pantai dengan perairan yang cukup tenang, dan bukan tempat yang ramai dikunjungi oleh wisatawan.

\section{Penutupan Terumbu Karang pada Lokasi Penelitian}

Berdasarkan hasil penelitian tutupan dasar perairan pada lokasi penelitian terdiri dari karang hidup, karang mati, pecahan karang dan pasir. Adapun data persentase tutupan dasar perairan pada lokasi penelitian tersaji pada tabel 2 dan tabel 3 berikut ini :

Tabel 2. Persentase penutupan substrat dasar pada lokasi penelitian.

\begin{tabular}{cccccc}
\hline \multirow{2}{*}{ No. } & \multirow{2}{*}{ Jenis Substrat } & $\mathrm{A}(\%)$ & $\mathrm{A}\left(\mathrm{cm}^{2}\right)$ & $\mathrm{B}(\%)$ & $\mathrm{B}\left(\mathrm{cm}^{2}\right)$ \\
\cline { 3 - 5 } & & 65,69 & 9853 & 69,26 & 10389 \\
1. & Karang Hidup & 17,83 & 2675 & 11,66 & 1749 \\
2. & Karang Mati & 8,41 & 1261 & 6,2 & 930 \\
3. & Pecahan Karang & 1211 & 12,88 & 1932 \\
4. & Pasir & 8,07 & 15000 & 100 & 15000
\end{tabular}

Sumber : Data Penelitian 2013 
http://ejournal-sl.undip.ac.id/index.php/maquares

Tabel 3. Persentase penutupan karang hidup pada lokasi penelitian.

\begin{tabular}{cccc}
\hline \multirow{2}{*}{ No. } & Genera & A $(\%)$ & Stasiun \\
\cline { 2 - 4 } 1. & Acropora & 21,58 & 16,38 \\
2. & Porites & 9,92 & 11,23 \\
3. & Fungia & 2,92 & 1,76 \\
4. & Montipora & 3,96 & 4,81 \\
5. & Miliopora & 3,58 & - \\
6. & Coeloceris & 4,26 & 5,6 \\
7. & Stylopora & 1,88 & 0,24 \\
8. & Goniastrea & 2,34 & 1,6 \\
9. & Favia & 1,78 & - \\
10 & Goniopora & 1,86 & - \\
11. & Turbinaria & 1,58 & 3,55 \\
12. & Pavona & 1,04 & 2,83 \\
13. & Merulina & 2,01 & 2,45 \\
14. & Milepora & 1,56 & - \\
15. & Cypastrea & 2,64 & 4,23 \\
16. & Heliopora & 0,57 & 0,92 \\
17. & Pocilopora & 1,6 & 0,8 \\
18. & Hydnopora & 1,16 & - \\
19. & Pectinia & - & 1,8 \\
20. & Galaxea & - & 1 \\
21. & Diploastrea & - & 5,05 \\
22. & Echinopora & - & 2,3 \\
23. & Pachyseris & - & 2,7 \\
\hline
\end{tabular}

Sumber : Data Penelitian 2013

Dari data tabel diatas didapatkan hasil persentase penutupan karang hidup sebesar pada stasiun A sebesar 65,69\% dan stasiun B sebesar 69,26\%. Untuk lebih jelasnya dapat dilihat pada gambar 1 .

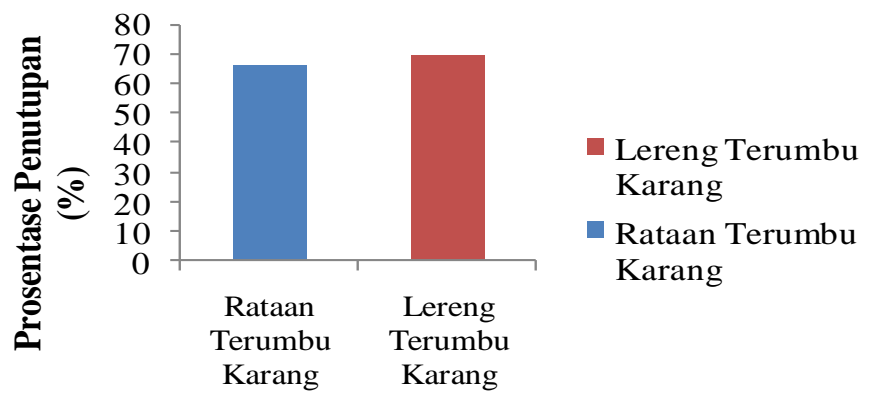

Gambar 1. Histogram Persentase Penutupan Karang Hidup

\section{Nilai Indeks Keanekaragaman (H') dan Indeks Keseragaman (e) Karang Hidup}

Hasil perhitungan nilai Indeks keanekaragaman dan keseragaman Karang Hidup pada lokasi penelitian tersaji pada tabel berikut ini.

Tabel 4. Indeks Keanekaragaman dan Keseragaman Terumbu Karang pada lokasi penelitian

\begin{tabular}{cccc}
\hline No. & Stasiun & H' & E \\
\hline 1. & A & 2,611 & 0,903 \\
2. & B & 2,603 & 0,901 \\
\hline
\end{tabular}

Berdasarkan data tabel diatas dapat dilihat bahwa nilai indeks keanekaragaman pada stasiun A sebesar 2,611 sedangkan pada stasiun B sebesar 2,603 dan nilai indeks keseragaman pada stasiun A dan stasiun B masing-masing sebesar 0,903 dan 0,901. 


\section{Jenis Teripang (Holothuroidea) yang ditemukan pada Lokasi Penelitian}

Jenis teripang (Holothuroidea) yang terdapat di Pulau Karimunjawa sangat berbagai macam jenisnya. Adapun jenis teripang yang ditemukan selama penelitian pada lokasi penelitian tersaji dalam tabel berikut ini.

Tabel 5. Jenis Teripang (Holothuroidea) yang ditemukan pada lokasi penelitian (Individu/ 300 meter $^{2}$ )

\begin{tabular}{|c|c|c|c|c|c|c|c|}
\hline \multirow{3}{*}{ No. } & \multirow{3}{*}{ Spesies } & \multicolumn{6}{|c|}{ Stasiun } \\
\hline & & \multicolumn{3}{|c|}{$\mathrm{A}$} & \multicolumn{3}{|c|}{$\mathrm{B}$} \\
\hline & & $\mathrm{I}$ & II & III & I & II & III \\
\hline 1. & Holothuria atra & 6 & 4 & 3 & 4 & 3 & 1 \\
\hline 2. & Holothuria scabra & 4 & 1 & 2 & - & - & - \\
\hline 3. & Bohadschia marmorata & 3 & 2 & 2 & - & - & - \\
\hline 4. & Holothuria fuscocinera & 3 & 2 & 1 & - & - & - \\
\hline 5. & Sticopus vastus & 2 & 1 & 1 & - & - & - \\
\hline 6. & Pearsonothuria graffei & - & - & - & - & 2 & 1 \\
\hline & Jumlah & 18 & 10 & 9 & 4 & 5 & 2 \\
\hline
\end{tabular}

Berdasarkan hasil penelitian didapatkan sebanyak 6 jenis spesies Teripang (Holothuroidea) yang diantaranya 5 jenis yang berada pada stasiun A dan 2 jenis yang berada pada stasiun B. Jenis spesies yang ditemukan pada stasiun A adalah Holothuria atra, Holothuria scabra, Bohadschia marmorata, Holothuria fuscocinera dan Sticopus vastus, sedangkan pada stasiun B jenis teripang yang ditemukan adalah Holothuria atra dan Pearsonothuria graffei.

Kelimpahan Teripang (Holothuroidea)

Tabel 6. Kelimpahan Relatif Teripang pada lokasi penelitian (Individu/ 300 meter $^{2}$ ).

\begin{tabular}{|c|c|c|c|c|c|}
\hline \multirow{3}{*}{ No. } & \multirow{3}{*}{ Spesies } & \multicolumn{4}{|c|}{ Stasiun } \\
\hline & & \multicolumn{2}{|c|}{$\mathrm{A}$} & \multicolumn{2}{|c|}{$\mathrm{B}$} \\
\hline & & $\mathrm{KI}$ & $\mathrm{KR}(\%)$ & KI & $\mathrm{KR}(\%)$ \\
\hline 1. & Holothuria atra & 13 & 35,13 & 8 & 72,72 \\
\hline 2. & Holothuria scabra & 7 & 18,51 & - & - \\
\hline 3. & Bohadschia marmorata & 7 & 18,51 & - & - \\
\hline 4. & Holothuria fuscocinera & 6 & 16,21 & - & - \\
\hline 5. & Sticopus vastus & 4 & 10,81 & - & - \\
\hline 6. & Pearsonothuria graffei & - & - & 3 & 27,27 \\
\hline & Jumlah & 37 & 100 & 11 & 100 \\
\hline
\end{tabular}

Keterangan : KI = Kelimpahan Individu

$\mathrm{KR}=$ Kelimpahan Relatif

Berdasarkan data dari tabel diatas maka dapat diperoleh histogram kelimpahan relatif (\%) teripang dari tiap-tiap stasiun selama penelitian tersaji pada gambar berikut :

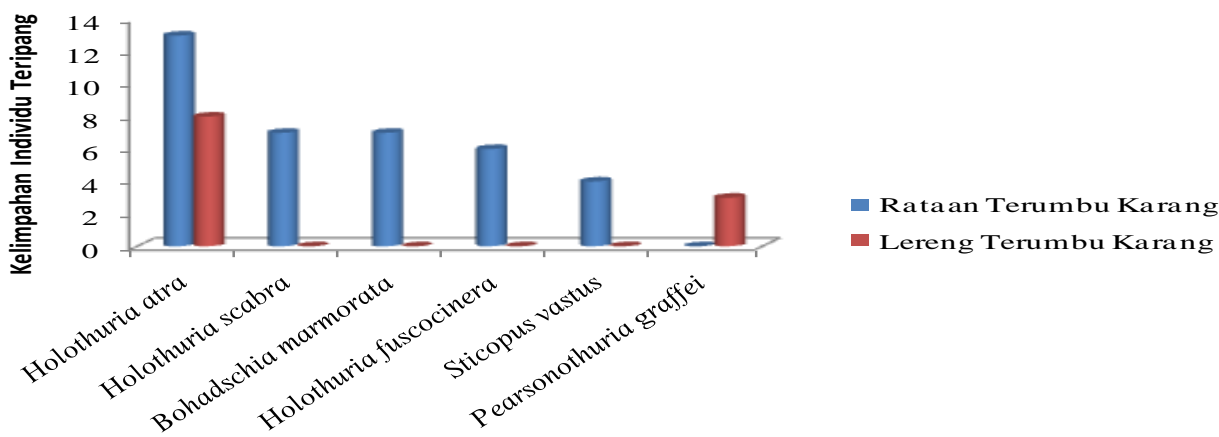

Gambar 2. Histogram Kelimpahan Teripang (Holothuroidea)

\section{Nilai Indeks Keanekaragaman (H') dan Indeks Keseragaman (e).}

Keanekaragaman dan Keseragaman jenis dihitung berdasarkan nilai Indeks Shannon-weaner (H') yang digunakan untuk mengevaluasi kondisi lingkungan perairan. Nilai Indeks Keanekaragaman dan Indeks Keseragaman teripang pada setiap lokasi penelitian pada kedua stasiun tersebut dipengaruhi oleh jumlah individu setiap jenis maupun jumlah seluruh jenis, dengan demikian nilai keanekaragaman dan keseragaman 
berbeda untuk tiap stasiunnya. Hasil pengukuran Nilai Indeks Keanekaragaman dan Keseragaman pada masing-masing lokasi selama penelitian tersaji pada tabel berikut :

Tabel 7. Nilai Indeks Keanekaragaman (H') dan Indeks Keseragaman (e) Teripang.

\begin{tabular}{cccc}
\hline No. & Stasiun & H' & E \\
\hline 1. & A & 1,532 & 0,306 \\
2. & B & 0,585 & 0,292 \\
\hline
\end{tabular}

Berdasarkan data dari tabel diatas, diperoleh Histogram Indeks Keanekaragaman dan Keseragaman jenis teripang selama penelitian tersaji pada gambar berikut :

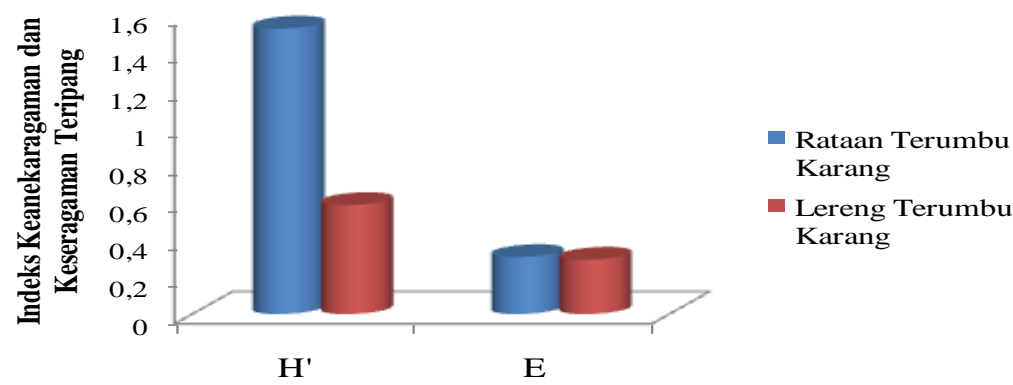

Gambar 3. Histogram Nilai Indeks Keanekaragaman dan Keseragaman Teripang

\section{Parameter Kualitas Air}

Berdasarkan hasil penelitian parameter fisika dan kimia perairan selama penelitian secara lengkap dapat dilihat pada tabel berikut ini :

Tabel 8. Parameter Kualitas Air pada lokasi penelitian.

\begin{tabular}{|c|c|c|c|c|c|}
\hline \multirow{2}{*}{ No. } & \multirow{2}{*}{ Parameter } & \multicolumn{2}{|c|}{ Stasiun } & \multirow{2}{*}{\multicolumn{2}{|c|}{ Pustaka }} \\
\hline & & $\mathrm{A}$ & B & & \\
\hline 1. & Suhu Air $\left({ }^{0} \mathrm{C}\right)$ & $30-31$ & $30-31$ & $20-31{ }^{\circ} \mathrm{C}$ & ( Nontji, 2005) \\
\hline 2. & Kedalaman (m) & $1,57-1,96$ & $2,75-3,65$ & Sampai dasar & (Sukarno, 1995) \\
\hline 3. & Salinitas $(\% / 00)$ & 31 & 33 & $30 \%-35 \%$ & (Dahuri, 2003) \\
\hline 4. & $\mathrm{pH}$ & 7 & 7 & $6,5-8,5$ & (Radisho, 1994) \\
\hline 5. & Kecerahan & $\sim$ & $\sim$ & - & \\
\hline
\end{tabular}

\section{Uji Test "T"}

Perbedaan kelimpahan teripang (Holothuroidea) pada daerah rataan terumbu karang dan lereng terumbu karang dapat di uji dengan data stastistik Uji Test " $T$ " menggunakan program SPSS.

\section{PEMBAHASAN}

Berdasarkan hasil penelitian ditemukan 23 jenis karang hidup pada lokasi penelitian. Jenis karang hidup tersebut yaitu dari Genus Acropora, Porites, Fungia, Montipora, Miliopora, Coeloceris, Stylopora, Goniastrea, Pavia, Goniopora, Turbinaria, Pavona, Merulina, Milepora, Cypastrea, Helipora, Pocilopora, Hydnopora, Pectinia, Galaxea, Diploastra, Echinopora dan Pachyseris.

Prosentase penutupan karang hidup tertinggi yaitu pada stasiun A yaitu Genus Acropora sebesar $21,58 \%$, Porites sebesar 9,92 dan Coeloceris sebesar 4,26\%. Sedangkan prosentase penutupan karang hidup tertinggi pada stasiun B yaitu Genus Acropora sebesar 16,38 \%, Porites sebesar 11,23\% dan Diploastrea sebesar $5,05 \%$.

Menurut Ardiwijaya (2010), sampai saat ini tercatat terdapat 69 genera karang yang termasuk dalam 14 famili ordo scleractinian dan 3 ordo non scleractinian dikawasan Balai Taman Nasional Karimunjawa. Jenis yang mendominasi ekosistem ini adalah genera Acropora dan Porites. Sampai dengan tahun 2009 tutupan karang keras di kawasan Taman Nasional Karimunjawa mencapai 54,64\%.

\section{Prosentase Penutupan Karang}

Berdasarkan hasil penelitian didapatkan nilai prosentase karang hidup pada stasiun A yaitu sebesar $65,69 \%$, sedangkan prosentase penutupan karang hidup pada stasiun B yaitu sebesar $69,26 \%$.

Adapun kondisi terumbu karang pada daerah rataan terumbu karang termasuk dalam kategori kondisi baik, sedangkan pada daerah lereng terumbu karang termasuk dalam kategori kondisi baik. Menurut Dahuri (2001), menyatakan bahwa kriteria penilaian kondisi terumbu karang yang baik adalah pada kisaran $50-70 \%$. 
Terumbu karang yang masih utuh atau yang masih baik mempunyai nilai estetika yang tinggi dan dapat dimanfaatkan pula untuk mendorong industri pariwisata laut. Kegiatan pariwisata memberikan kesempatan orang untuk menyelam, mengamati dan memotret kekayaan serta keindahan bawah air ini semakin berkembang di Indonesia dan dapat merupakan penghasil devisa (Nontji, 2005).

Ekosistem terumbu karang mempunyai produktivitas organik yang tinggi. Hal ini disebabkan oleh kemampuan terumbu karang untuk menahan nutrien dalam sistem dan berperan sebagai kolam untuk menampung segala masukan dari luar (Nybakken, 1986).

\section{Indeks Keanekaragaman (H') dan Keseragaman (e) Penutupan Karang Hidup}

Berdasarkan hasil analisa, didapatkan nilai indeks keanekaragaman $\left(\mathrm{H}^{\prime}\right)$ penutupan karang hidup pada stasiun A yaitu sebesar 2,611, sedangkan pada stasiun B yaitu sebesar 2,603. Nilai indeks keseragaman (e) penutupan karang hidup pada stasiun A yaitu sebesar 0,903 sedangkan pada stasiun B yaitu sebesar 0,901.

Menurut Sukarno (1981) mengatakan bahwa semakin tinggi nilai keanekaragaman (H') pada suatu perairan, maka perairan tersebut mempunyai tingkat produktivitas yang tinggi.

Dari pernyataan tersebut maka Indeks keseragaman karang hidup pada stasiun A dalam tingkat keseragaman tinggi dan indeks keseragaman pada stasiun B dalam tingkat keseragaman tinggi karena nilai (E) pada keduanya diatas 0,6.

\section{Kelimpahan Jenis Teripang (Holothuroidea)}

Berdasarkan hasil penelitian didapatkan pada lokasi penelitian sebanyak 6 jenis teripang. Jenis-jenis teripang tersebut diantaranya Holothuria atra, Holothuria scabra, Bohadschia marmorata, Holothuria fuscocinera, Sticopus vastus dan Pearsonothuria graffei. Pada stasiun A didapatkan kelimpahan individu teripang sebanyak $37 \mathrm{ind} / 300 \mathrm{~m}^{2}$. Untuk Holothuria atra sebanyak $13 \mathrm{ind} / 300 \mathrm{~m}^{2}$, Holothuria scabra sebanyak 7 ind/ $300 \mathrm{~m}^{2}$, Bohadschia marmorata sebanyak 7 ind/ $300 \mathrm{~m}^{2}$, Holothuria fuscocinera sebanyak 6 ind/ $300 \mathrm{~m}^{2}$ dan Sticopus vastus sebanyak $4 \mathrm{ind} / 300 \mathrm{~m}^{2}$. Sedangkan untuk Pearsonothuria graffei tidak ditemukan pada lokasi tersebut. Pada stasiun B didapatkan kelimpahan individu teripang sebanyak 11 ind/ $300 \mathrm{~m}^{2}$ dari dua jenis spesies teripang yang ditemukan. Speseies tersebut diantaranya yaitu Holothuria atra sebanyak 8 ind / $300 \mathrm{~m}^{2}$ dan Pearsonothuria graffei sebanyak 4 ind/ $300 \mathrm{~m}^{2}$.

Adapun didapatkan kelimpahan relatif teripang pada lokasi penelitian yaitu pada stasiun A kelimpahan relatifnya sebesar $100 \%$ yang dimana Holothuria atra sebesar 35,13\%, Holothuria scabra sebesar 18,51 \%, Bohadschia marmorata sebesar 18,51\%, Holothuria fuscocinera sebesar 16,21\% dan Sticopus vastus sebesar 10,81\%. Sedangkan untuk Pearsonothuria graffei tidak ditemukan pada lokasi tersebut. Pada daerah stasiun B didapatkan kelimpahan relatifnya sebesar $100 \%$ dari dua jenis spesies yang ditemukan di lokasi tersebut. Jenis teripang tersebut diantaranya Holothuria atra sebesar 72,72\% dan Pearsonothuria graffei sebesar 27,27\%.

Berdasarkan hasil analisa diatas, diketahui bahwa kelimpahan jenis teripang tertinggi adalah jenis spesies Holothuria atra dengan nilai kelimpahan individu sebesar 35,13\% yang berada pada stasiun A.

Menurut Purwati (2008) Holothuria atra dikenal sebagai teripang darah karena cairan kemerahan yang dimilikinya jika permukaan tubuhnya digosok. Holothuria atra menyukai tempat terbuka ditempat yang selalu tergenang pada pasang surut yang biasanya memiliki daerah bersubstrat keras dan kasar.

\section{Indeks Keanekaragaman (H') dan Keseragaman (e) Teripang}

Berdasarkan hasil penelitian didapatkan indeks keanekaragaman teripang pada stasiun A sebesar 1,532 dan pada stasiun B sebesar 0,585. Hal tersebut menyatakan bahwa indeks keanekaragaman teripang pada stasiun A dalam kisaran sedang dan pada stasiun B menyatakan bahwa indeks keanekaragaman teripang dalam kisaran rendah. Menurut Poole (1974) dalam Suprapti (1993) keanekaragaman tidak hanya dilihat dari banyaknya jenis tetapi juga dari penyebaran individu dalam tiap jenisnya dan tergantung dari kelimpahan individu dalam spesies.

Berdasarkan hasil penelitian didapatkan indeks keseragaman teripang pada stasiun A sebesar 0,306 dan pada stasiun B sebesar 0,292. hal tersebut menyatakan bahwa indeks keseragaman teripang pada stasiun A dalam tingkat keseragaman populasi kecil dan pada stasiun B menyatakan bahwa indeks keseragaman teripang dalam tingkat keseragaman populasi kecil.

Menurut Wilham dan Dorris (1986) menyatakan bahwa indeks keanekaragaman akan mencapai maksimum bila kelimpahan individu per jenis menyebar secara merata yang berarti jumlah individu setiap jenisnya relatif sama (seragam). Dikatakan lebih lanjut semakin kecil pula keseragaman jenis dalam komunitas, artinya penyebaran jumlah individu setiap jenis tidak sama. Ada kecenderungan bahwa komunitas tersebut didominasi oleh sesuatu spesies atau jenis tertentu. Sebaliknya semakin besar nilai indeks keseragaman (menjauhi nol) dalam komunitas akan menyebabkan keseragaman jenis semakin besar, artinya kelimpahan setiap jenis dapat dikatakan sama atau tidak jauh berbeda dan di dalam komunitas tersebut tidak dapat didominasi.

\section{Perbedaan Kelimpahan Teripang (Holothuroidea) di Rataan Terumbu Karang dengan Lereng} Terumbu Karang

Berdasarkan hasil penelitian didapatkan kelimpahan jenis teripang pada stasiun A daerah rataan terumbu karang lebih banyak dibandingkan dengan stasiun B lereng terumbu karang. Perbedaan kelimpahan 
tersebut dapat dipengaruhi oleh kedalaman, dimana pada rataan terumbu karang lebih dangkal dibandingkan lereng terumbu karang yang memungkinkan cahaya matahari dapat masuk kedalam suatu perairan tersebut secara merata. Dari hal tersebut fitoplankton dan alga dapat berfotosintesis dengan baik dan dapat menghasilkan makanan bagi organisme-organisme yang ada di daerah tersebut termasuk teripang.

Adapun dari hasil uji statistik dengan Uji Test " $\mathrm{T}$ " menggunakan program SPSS dapat dinyatakan bahwa kelimpahan jenis teripang yang paling banyak adalah pada rataan terumbu karang,

karena nilai signifikasinya lebih dari $\geq 0,05$ sehingga terima $\mathrm{H}_{1}$ tolak $\mathrm{H}_{0}$.

\section{Parameter Kualitas Air}

Parameter kualitas air sangat mempengaruhi kondisi ekosistem terumbu karang dan kelimpahan teripang. Pengukuran parameter kualitas air yang diukur diantaranya suhu air, kedalaman, salinitas, $\mathrm{pH}$ dan kecerahan. Hasil Pengukuran suhu air yaitu pada stasiun A dan stasiun B berkisar antara $30-31{ }^{\circ} \mathrm{C}$. Teripang membutuhkan kisaran suhu perairan yang ideal untuk menunjang kehidupan di dalam ekosistem tempat dimana teripang akan berkembang dengan baik. Menurut Sutaman (1992), bahwa suhu yang baik untuk kehidupan teripang berkisar antara $22{ }^{\circ} \mathrm{C}-32{ }^{\circ} \mathrm{C}$, maka dari hasil pernyataan tersebut, kisaran suhu air pada lokasi penelitian masih sangat ideal untuk menunjang kehidupan teripang. Selain untuk menunjang kehidupan teripang, suhu air juga harus menunjang ekosistem terumbu karang, dimana tempat tempat teripang tersebut hidup. Menurut Nybakken (1992), bahwa karang akan tumbuh baik pada suhu $25-29{ }^{\circ} \mathrm{C}$ dan masih memiliki toleransi sampai dengan suhu $40{ }^{\circ} \mathrm{C}$.

Pengukuran salinitas perairan pada lokasi sampling yaitu pada stasiun A dan stasiun B mendapatkan hasil yaitu $31-33 \%$. Setiap jenis terumbu karang mempunyai batas untuk menolerir kadar salinitas masingmasing untuk menunjang kehidupan dari terumbu karang tersebut. Dahuri (2003), menyatakan bahwa banyak spesies karang peka terhadap perubahan salinitas yang besar. Umumnya terumbu karang tumbuh dengan baik disekitar wilayah pesisir pada salinitas $30-35 \%$. Teripang yang hidup didalam ekosistem terumbu karang juga memiliki kadar toleransi terhadap salinitas. Menurut Sutaman (1992), bahwa salinitas yang baik untuk kehidupan teripang berkisar antara $26-33 \%$.

Kedalaman sangat berhubungan dengan kecerahan perairan. Kecerahan yang tinggi membuat penetrasi cahaya semakin tinggi, faktor ini sangat berhubungan dengan ketersediaan cahaya dan tingkat kecerahan perairan. Kecerahan pada lokasi sampling yaitu pada stasiun A dan stasin B juga mendapatkan hasi yang berbeda, dimana pada stasiun A yaitu berkisar antara 1,57 - 1,96 meter sedangkan pada stasiun B berkisar antara 2,75 - 3,65 meter. Kedalaman perairan berpengaruh terhadap tingkat intensitas cahaya matahari yang masuk kedalam suatu perairan yang dapat dimanfaatkan oleh organisme-organisme berklorofil untuk melakukan fotosintesis. Menurut Sukarno (1995), menyatakan bahwa terumbu karang tidak dapat tumbuh pada kedalaman perairan lebih dari 50 meter. Pertumbuhan karang dibatasi oleh kedalaman yang berhubungan dengan penetrasi cahaya matahari yang masuk kedalam kolom air.

Pengukuran $\mathrm{pH}$ pada lokasi sampling yaitu pada stasiun A dan stasiun B mendapatkan hasil yaitu 7 . Kisaran tersebut masih masih dalam batas toleransi bagi terumbu karang untuk dapat tumbuh dan berkembang dengan baik. Terumbu karang umumnya tumbuh pada kisaran $\mathrm{pH}$ normal. Hal tersebut sesuai dengan pernyataan Radisho (1994), bahwa pH yang menunjang bagi kehidupan karang berkisar antara 6,5 8,5 .

\section{KESIMPULAN}

Kesimpulan yang diperoleh dari penelitian yang telah dilakukan adalah :

1. Kelimpahan jenis teripang (Holothuroidea) pada rataan terumbu karang sebesar $37 \mathrm{ind} / 150 \mathrm{~m}^{2}$ yang diantaranya spesies Holothuria atra sebanyak 13 ind/ $300 \mathrm{~m}^{2}$, spesies Holothuria scabra sebanyak 7 ind/ $300 \mathrm{~m}^{2}$, spesies Bohadschia marmorata sebanyak $7 \mathrm{ind} / 300 \mathrm{~m}^{2}$, Holothuria fuscocinera sebanyak 6 ind/ $300 \mathrm{~m}^{2}$ dan Sticopus vastus sebanyak 4 ind/ $300 \mathrm{~m}^{2}$, sedangkan pada lereng terumbu karang kelimpahan teripang didapatkan sebanyak 11 ind/ $300 \mathrm{~m}^{2}$ yang diantaranya spesies Holothuria atra sebanyak 8 ind/ $300 \mathrm{~m}^{2}$ dan spesies Pearsonothuria graffei sebanyak 3 ind $/ 300 \mathrm{~m}^{2}$.

2. Berdasarkan hasil perhitungan dengan menggunakan analisa data Chi Kuadrat menyatakan bahwa ada hubungan tutupan karang dengan kelimpahan teripang di lokasi penelitian.

\section{SARAN}

Saran yang dapat diberikan adalah:

1. Perlunya dilakukan penelitian pada malam hari agar mendapatkan hasil yang bervariatif;

2. Perlunya ada kegiatan konservasi terumbu karang untuk tetap menjaga kelestarian dialammnya; dan

3. Perlu dilakukan pembudidayaan teripang melihat kondisi jumlah teripang dilokasi penelitian sudah semakin sedikit.

\section{Ucapan Terima Kasih}

Penulis mengucapkan terimakasih kepada Ir. Ruswahyuni, M.Sc dan Dr. Ir. Suryanti, M.Pi yang telah memberikan saran, motivasi dan bimbingan dalam penyusunan jurnal ini. 


\section{DAFTAR PUSTAKA}

Ardiwijaya, R.L, Paradede, S.T., Kartikawijaya, T., Prasetia, R., Setiawan, F. 2010. Laporan Teknis Monitoring Ekologi Taman Nasional Karimunjawa 2009, Monitoring Fase 4. WCS-IPB. Bogor. hlm. 8.

BTNKj. 2008. Laporan Pelaksanaan Kegiatan Pembinaan Habitat Teripang TNKj Tahun 2008, Semarang, 28 hlm.

Dahuri, R, Rais, J., Ginting, S.P., dan Sitepu, M.J.. 2001. Pengelolaan Sumberdaya Wilayah Pesisir dan Lautan Secara Terpadu. PT. Pradnya Paramita. Jakarta.

Effendi, H. 2003. Telaah Kualitas Air. Bagi Pengelolaan Sumber Daya dan Lingkungan Perairan. Kanisius (Anggota IKAPI). Yogyakarta.

Ghufran, M. dan Andi Baso. 2005. Pengelolaan Kualitas Air dalam Budidaya Perairan, Rineka Cipta, Jakarta, 36-55 hlm.

Hutabarat, S. 2000. Produktivitas Perairan dan Plankton. Telaah Terhadap Ilmu perikanan dan Ilmu Kelautan. Badan Penerbit UNDIP. Semarang

Irawan, P. 2002. Logika dan Prosedur Penelitian, Pengantar Teori dan Panduan Praktis Penelitian Sosial Bagi Mahasisiwa dan Peneliti Pemula. Cet. 1 STIA-LAN: Jakarta, $303 \mathrm{hlm}$.

Murdiyanto. 2003. Mengenal, Memelihara dan Melestarikan Ekosistem Terumbu Karang. DKP : Jakarta.

Nontji, A. 2005. Laut Nusantara. Djambatan. Jakarta. hlm. 126.

Notoatmodjo, S. 2002. Metode Penelitian Kesehatan. Rineke Cipta, Jakarta, 207 hal.

Nybakken, J.W. 1986. Biologi Laut: Suatu Pendekatan Ekologi. (Penerjemah : M. Eidman; Koesoebiono; Dietrich; Hutomo; dan Sukardjo). PT. Gramedia, Jakarta.

Sudjana. 2002. Metode Statistik. Tarsito, Bandung.

Sukarno, H., M, Moosa dan M.K. Darsono, P. 1981. Terumbu Karang di Indonesia. Sumberdaya Permasalahan dan Pengelolaannya. LON-LIPI, Jakarta.

Suprapti, N., Sugondo, H.., Hadi, M. dan Tarwodjo, U.. 1993. Studi Plankton di Sekitar Daerah PLTU. Semarang. 7 hlm. (tidak dipublikasikan)

Supriharyono. 2000. Pengelolaan Ekosistem Terumbu Karang. Djambatan : Jakarta.

Suryanto,A. 1986. Penelitian Pertumbuhan Beberapa Spesies Karang di Perairan Pantai Bandengan dan Perairan Pulau Panjang Jepara. Universitas Diponegoro, Semarang.

Odum, E. P . 1971. Fundamental of Ecology. Gajah Mada University Press. Yogyakarta. . 1993. Fundamental of Ecology. Gajah Mada University Press. Yogyakarta.

Purwati, P.A.S. 2008. Timun Laut Lombok Barat: Ikatan sarjana Oseanologi Indonesia. LIPI : Jakarta. 